\title{
Perancangan Sistem Kepuasan Masyarakat Terhadap Pelayanan Publik Dengan Metode Analytical Hierarchy Process (AHP)
}

\author{
Petrus Sokibi ${ }^{1}$, Nurul Bahiyah ${ }^{2}$ \\ Sekolah Tinggi Manajemen Informatika dan Komputer CIC \\ J1. Kesambi 202 Kota Cirebon, Jawa Barat Tlp: (0231)220250. \\ E-mail: petrus.sokibi@cic.ac.id
}

\begin{abstract}
Talun sub-district is a government institution that provides public services to the public, which at this time there is no assessment of service satisfaction from the community, so that the District Talun can not know the assessment or complaints from the public to public services provided. The research aims to determine the level of public satisfaction of Public Service in Talun Sub-district. AHP is a complex multi-criteria decisionmaking method, in an unstructured situation into sections that are then shaped into functional hierarchies to present problems to be solved and then build a priority sequence for alternatives by pairwise alternative comparisons based on judgments of decision makers against system. The appraisal application yields the value of the public satisfaction level and the eigen vector ranked according to the highest data as the final value of the AHP calculation, so that the eigenvector value obtained can facilitate the Camat to see which elements of service are not good.
\end{abstract}

Keywords : Satisfaction, Service, SPK, AHP

\section{PENDAHULUAN}

Pelayanan publik oleh aparatur pemerintah dewasa ini masih banyak dijumpai kelemahan sehingga belum dapat memenuhi kualitas yang diharapkan masyarakat. Hal ini ditandai dengan masih adanya berbagai keluhan masyarakat yang disampaikan melalui media massa, sehingga dapat menimbulkan citra yang kurang baik terhadap aparatur pemerintah. Mengingat fungsi utama pemerintah adalah melayani masyarakat maka pemerintah perlu terus berupaya meningkatkan kualitas pelayanan.

Salah satu upaya untuk meningkatkan kualitas pelayanan publik, sebagaimana diamanatkan dalam Undang-undang Republik Indonesia Nomor 25 Tahun 2000 tentang Program Pembangunan Nasional (PROPENAS), perlu disusun indeks kepuasan masyarakat sebagai tolak ukur untuk menilai tingkat kualitas pelayanan. Di samping itu data indeks kepuasan masyarakat akan dapat menjadi bahan penilaian terhadap unsur pelayanan yang masih perlu perbaikan dan menjadi pendorong setiap unit penyelenggara pelayanan untuk meningkatkan kualitas pelayanannya (KEPMENPAN No. 25 Tahun 2004).

Kecamatan Talun merupakan salah satu kantor pemerintahan yang aktivitasnya memberikan pelayanan publik kepada masyarakat. Jumlah pengunjung dari tahun ke tahun terjadi peningkatan dari semua kategori pelayanan untuk masyarakat Kecamatan Talun, sehingga unit pelayanan di Kecamatan Talun perlu ditingkatkan agar kualitas pelayanan lebih baik dan cepat.

Salah satu harapan masyarakat adalah mengharapkan meningkatkan pelayanan yang lebih baik dan cepat, sebagian masyarakat selalu mengeluh dan kecewa terhadap pelayanan yang diberikan, pelayanan 
yang diberikan secara umum masih rendah dan belum memuaskan masyarakat, pelayanan yang diberikan terlalu berbelit-belit dengan berbagai alasan yang kurang dapat diterima oleh masyarakat, sehingga pelayanan yang diberikan masih dikatakan belum maksimal. Permasalahan yang masih sering dikeluhkan oleh sebagian masyarakat adalah waktu pelayanan, waktu pemrosesan layanan kepada masyarakat sekitar dua minggu dianggap masih terlalu lama bagi masyarakat, walaupun lamanya layanan tersebut telah sesuai dengan ketentuan tentang standar waktu pelayanan publik yang ditetapkan.

Dari survey lapangan yang dilakukan di Kecamatan Talun, penulis memperoleh informasi bahwa pejabat di sana belum memiliki sistem penilaian untuk mengetahui kepuasan masyarakat berkaitan dengan pelayanan yang diberikan kepada masyarakat di Kecamatan Talun. Hal ini menyebabkan pihak kecamata tidak dapat mengetahui bidang pelayanan yang belum dilakukan dengan maksimal dan memerlukan peningkatan.

Agar penelitian ini lebih terarah, penulis membatasi aspek penelitian yang dilakukan yaitu pada bagaimana membangun sistem berbasis website dengan menggunakan metode Analytical Hierarchy Process (AHP) untuk menentukan prioritas kepuasan masyarakat. Sistem dirancang dengan menyediakan 3 (tiga) user yaitu user umum yaitu masyarakat, user admin yaitu petugas kecamatan yang mempunyai hak untuk mengelola sistem dan camat yang mempunyai akses untuk melihat hasil penilaian dari masyarakat.

Tujuan penelitian yang dilakukan oleh penulis adalah membuat sebuah aplikasi sistem penunjang keputusan menggunakan metode AHP dengan berbasis website untuk mengetahui penilaian masyarakat dari data pengisian kuesioner secara online. Sistem ini bertujuan untuk mempermudah masyarakat memberikan nilai terhadap pelayanan publik di Kecamatan Talun. Sistem akan mencari nilai eigen vektor dengan merangking sesuai urutan nilai data tertinggi sebagai nilai hasil akhir perhitungan AHP, sehingga nilai eigen yang diperoleh dapat membantu Kecamatan Talun dalam meningkatkan pelayanan kepada masyarakat di sana.

\section{METODE}

\section{Pengertian Sistem Penunjang Keputusan}

Menurut Kusrini (2007, P15) sistem pendukung keputusan merupakan sistem informasi interaktif yang menyediakan informasi, pemodelan dan yang pemanipulasi data. Sistem ini digunakan untuk membantu mengambil keputusan dalam situasi yang semi terstruktur dan tidak terstruktur, dimana tidak seorang pun tahu secara pasti bagaimana keputusan seharusnya dibuat [2].

\subsection{Karakteristik Sistem Penunjang Keputusan}

Menurut Kusrini (2007, P16) ada beberapa karakteristik umum yang membantu kita memahami dalam definisi Sistem Penunjang Keputusan.

1. Menunjang pembuatan keputusan manajemen dalam menangani masalah semi terstruktur dan tidak terstruktur.

2. Membantu manajer pada berbagai tingkatan manajemen, mulai dari manajemen tingkat atas sampai manajemen tingkat bawah.

3. Menunjang pembuatan keputusan secara kelompok dan perorangan, menunjang pembuatan keputusan yang saling bergantungan dan berurutan, penunjang tahap pembuatan keputusan antara lain intelligence, design, choice dan implementation. 
4. Menunjang berbagai bentuk proses pembuatan keputusan dan jenis keputusan, kemampuan untuk melakukan adaptasi setiap saat dan bersifat fleksibel, kemudahan melakukan interaksi sistem, dan meningkatkan efektivitas dalam pembuatan keputusan dari pada efisiensi.

5. Mudah dikembangkan oleh pemakai akhir, kemampuan pemodelan dan analisis dalam pembuatan keputusan, kemudahan melakukan pengaksesan berbagai sumber dan format data [2].

\subsection{Analytical Hierarchy Process (AHP)}

Menurut Kusrini (2007, P133) Analytical Hierarchy Process (AHP) adalah metode keputusan multi kriteria untuk pemecahan masalah yang kompleks atau rumit, dalam situasi tak terstruktur menjadi bagian- bagian (variabel) yang kemudian dibentuk menjadi hierarki fungsional atau terstruktur network untuk menampilkan permasalahan yang akan dipecahkan dan kemudian membangun urutan prioritas untuk alternative melalui perbandingan berpasangan alternative yang ada berdasarkan penilaian dari pembuat keputusan terhadap sistem Analytical Hierarchy Process. Analytical Hierarchy Process yang dikembangkan oleh Prof. Thomas Lorie Saaty dari Wharton School Business merupakan model keputusan yang mirip/identik dengan model perilaku politis yaitu merupakan model keputusan individual dengan pendekatan kolektif dari pengambilan keputusannya.

Adapun kelebihan dari model AHP dibandingkan dengan yang lainnya:

1. Struktur yang berharapkan, sebagai konsekuensi dari kriteria yang dipilih, sampai pada sub kriteria yang paling dalam.

2. Memperhitungkan validitas sampai dengan batas toleransi inkonsistensi berbagai kriteria dan alternatif yang dipilih oleh para pengambil keputusan.

3. Memperhitungkan daya tahan atau ketahanan output analisis sensitivitas pengambil keputusan.

4. Kemampuannya memecahkan masalah yang multi objektif dan multi kriteria.

Di samping itu, model AHP juga memiliki kelemahan yang dapat berakibat fatal, misalnya ketergantungan model pada input berupa persepsi seorang expert akan membuat hasil akhir dari model ini menjadi tidak ada artinya apabila orang expert tersebut memberikan penilaian yang keliru [2].

\subsubsection{Prinsip Kerja AHP}

Menurut Kusrini (2007, P133) dalam menyelesaikan persoalan dengan metode Analytic Hierarchy Process (AHP) ada beberapa prinsip dasar yang harus dipahami antara lain:

\section{Dekomposisi (Decomposition)}

Pengertian dekomposisi adalah memecahkan atau membagi problema yang utuh menjadi unsurunsurnya ke bentuk hierarki proses pengambilan keputusan, dimana setiap unsur atau elemen saling berhubungan. Untuk mendapatkan hasil yang akurat, pemecahan dilakukan terhadap unsur-unsur sampai tidak mungkin dilakukan pemecahan lebih lanjut, sehingga didapatkan beberapa tingkatan dari persoalan yang hendak dipecahkan. Struktur hierarki keputusan tersebut dapat dikategorikan sebagai complete dan incomplete. Suatu hierarki keputusan disebut complete jika semua elemen pada suatu tingkat memiliki hubungan terhadap semua elemen yang ada pada tingkat berikutnya.

2. Perbandingan Penilaian (Comparative Judgement)

Perbandingan penilaian dilakukan dengan penilaian tentang kepentingan relatif dua elemen pada suatu tingkat tertentu dalam kaitannya dengan tingkatan di atasnya. Penilaian ini merupakan inti dari AHP karena akan berpengaruh terhadap urutan prioritas dari elemen-elemennya. Hasil dari penilaian ini lebih mudah disajikan dalam bentuk matrix pairwise comparisons yaitu matriks perbandingan berpasangan memuat tingkat preferensi beberapa alternatif untuk tiap kriteria [2]. 
Tabel 1. Skala Penilaian Perbandingan Berpasangan

\begin{tabular}{|c|l|}
\hline $\begin{array}{c}\text { Intensitas } \\
\text { Kepentingan }\end{array}$ & \multicolumn{1}{c|}{ Keterangan } \\
\hline 1 & Kedua elemen sama pentingnya \\
\hline 3 & Elemen yang satu sedikit lebih penting daripada elemen yang lainnya \\
\hline 5 & Elemen yang satu lebih penting daripada elemen lainnya \\
\hline 7 & Satu elemen jelas lebih mutlak penting daripada elemen lainnya \\
\hline 9 & Satu elemen jelas mutlak penting daripada elemen lainnya \\
\hline $2,4,6,8$ & Nilai-nilai antara dua nilai pertimbangan yang berdekatan \\
\hline Kebalikan & $\begin{array}{l}\text { Jika aktivitas i mendapat satu angka dibandingkan dengan aktivitas j, maka i memiliki } \\
\text { nilai kebalikannya dibandingkan dengan i }\end{array}$ \\
\hline
\end{tabular}

\section{ANALISIS DAN PERANCANGAN}

\subsection{Analisis Sistem yang Berjalan}

Sistem untuk mengetahui penilaian masyarakat terhadap pelayanan publik di Kecamatan Talun pada saat ini belum ada baik secara manual maupun secara komputerisasi, sehingga pihak Kecamatan Talun tidak dapat mengetahui penilaian atau keluh kesah dari masyarakat terhadap pelayanan publik yang di berikan.

\subsection{Perancangan Sistem}

Tahap desain sistem secara umum dilakukan setelah tahap analisis sistem selesai maka melakukan tahap perancangan sistem. Karena hasil analisis sistem masih belum ada baik secara manual maupun secara komputerisasi, maka dapat dibuat atau dirancang dengan sistem yang baru.

\subsubsection{Model Use case}

Model use case menjelaskan mengenai aktor-aktor yang terlibat dengan perangkat lunak yang dibangun beserta proses-proses yang ada di dalamnya.

1. Use case Diagram

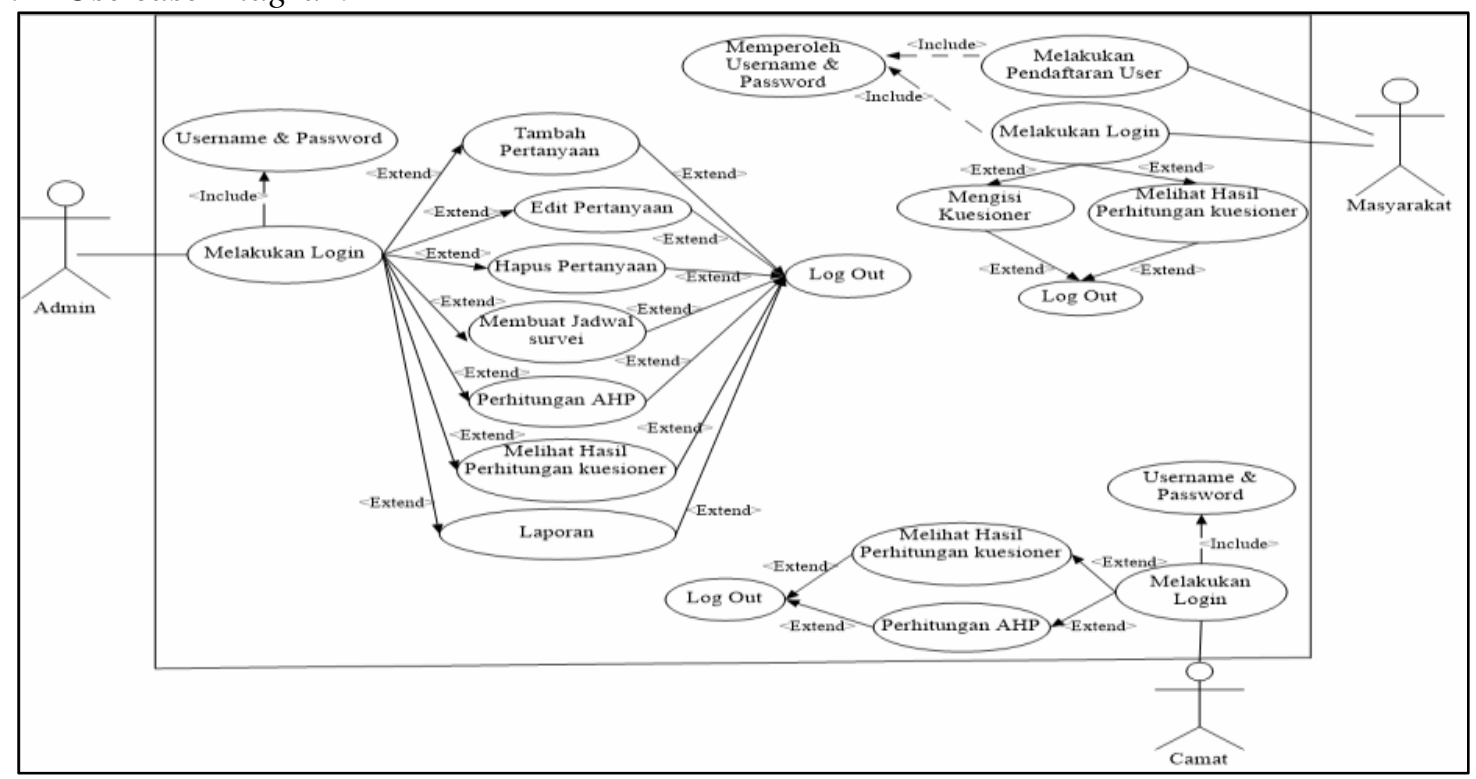

Gambar 1. Use Case Diagram Pengisian Kuesioner 


\section{Keterangan:}

Pada sistem ini terdiri dari 3 (tiga) user, yang pertama Admin sebagai orang yang mempunyai hak akses khusus untuk mengelola sistem dan melakukan perhitungan AHP, yang kedua Masyarakat yaitu sebagai pengguna aplikasi untuk melakukan pengisian kuesioner, dan yang ketiga Camat yaitu orang yang mempunyai hak akses khusus untuk melihat hasil penilaian dari masyarakat.

\subsubsection{Activity Diagram}

Activity diagram adalah teknik untuk menggambarkan logika prosedural, proses bisnis, jalur kerja, dan activity diagram juga sebagai salah satu untuk memperoleh event-event yang terjadi dalam suatu use case. Berikut ini activity diagram dari sistem kepuasan masyarakat terhadap pelayanan publik di Kecamatan Talun :

1. Activity Diagram Pengisian Kuesioner

Layout activity diagram ini menjelaskan proses pengguna atau masyarakat untuk melakukan penilaian pelayanan publik dengan melakukan pengisian kuesioner. Masyarakat melakukan pendaftaran user, melakukan login dengan menginputkan username dan password, klik menu kuesioner, klik menu jadwal pengisian kuesioner, mengisi kuesioner, dan simpan. Layout diagramnya dapat dilihat pada Gambar 2. 


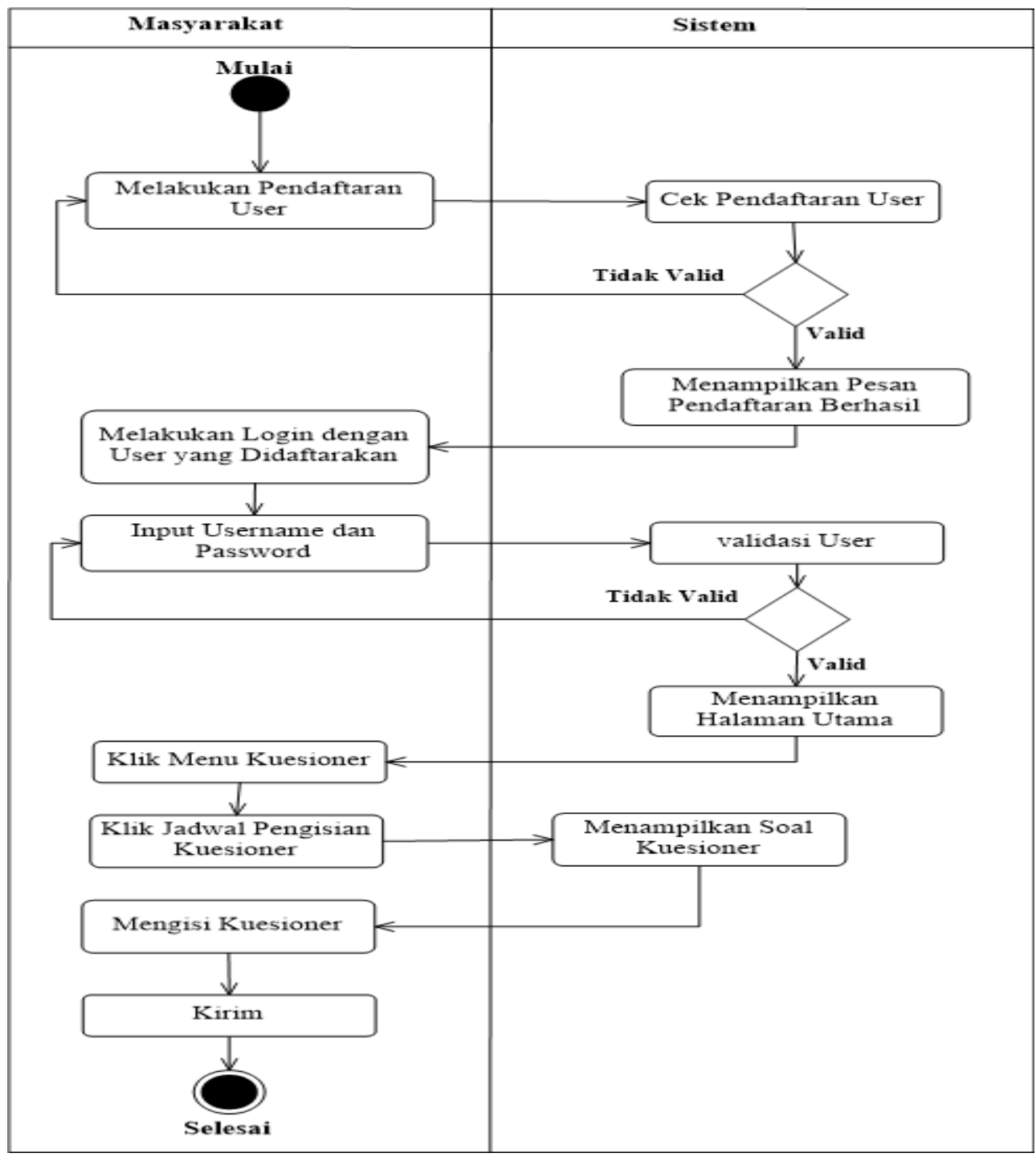

Gambar 2. Activity Diagram Pengisian Kuesioner

2. Activity Diagram Membuat Jadwal Survei

Petugas (admin) melakukan login terlebih dahulu. Kemudian sistem akan memvalidasi apakah username dan password tersebut benar atau tidak. Jika benar maka sistem akan mengarahkan ke halaman admin, yang terdiri dari beberapa menu diantaranya Home, Data Master, Data Survei, Kelola Jadwal, Laporan dan Analisa AHP, kemudian pilih menu kelola jadwal. Layout Activity Diagramnya dapat dilihat pada Gambar 3. 


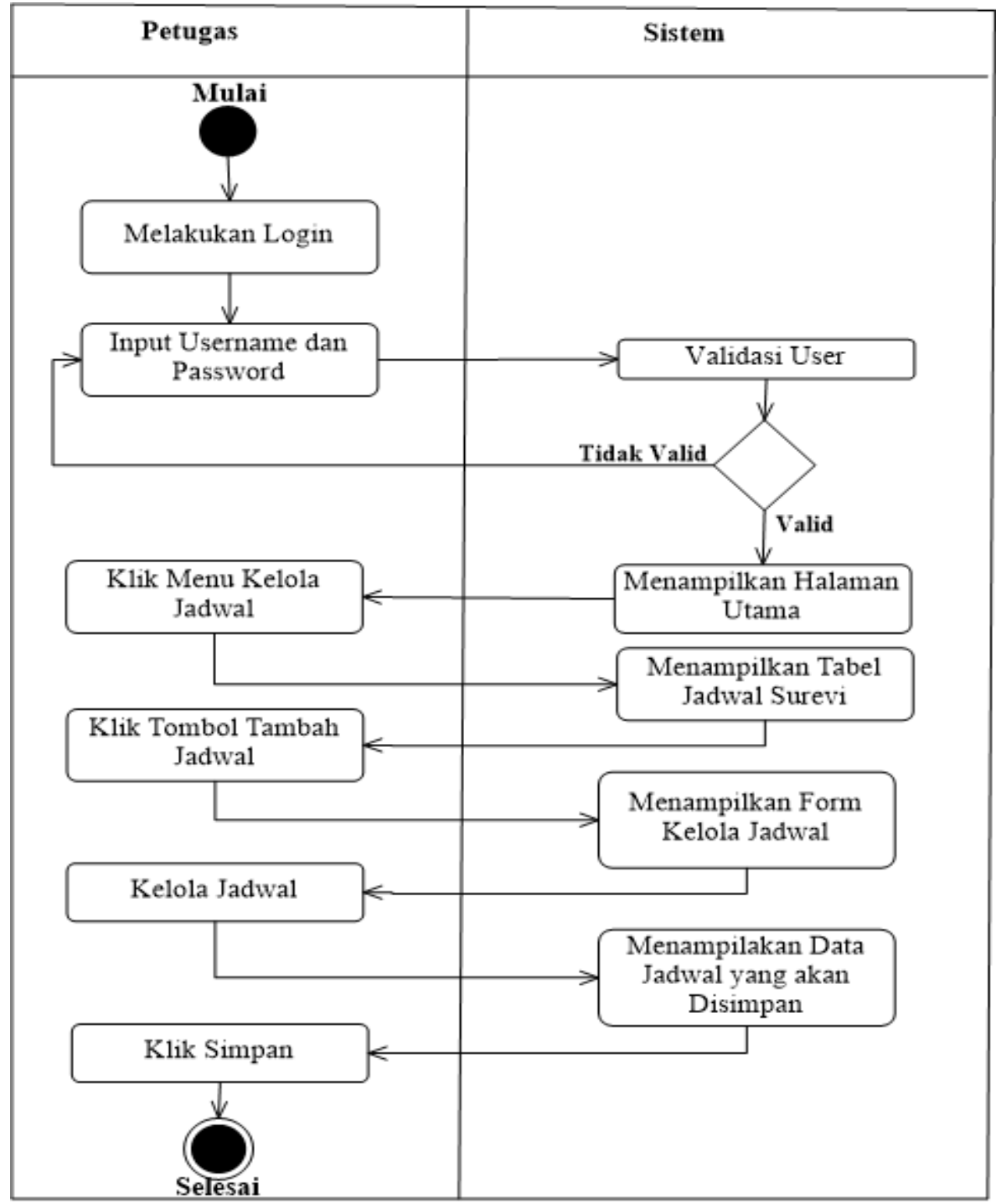

Gambar 3. Activity Diagram Membuat Jadwal Survei

3. Activity Diagram Perhitungan AHP

Layout activity diagram ini menjelaskan petugas (admin) melakukan login terlebih dahulu. Kemudian sistem akan memvalidasi apakah username dan password tersebut benar atau tidak. Jika benar maka sistem akan mengarahkan ke halaman admin, yang terdiri dari beberapa menu diantaranya Home, Data Master, Data Survei, Kelola Jadwal, Laporan dan Analisa AHP, kemudian admin pilih menu Analisa AHP. Layout Activity Diagramnya dapat dilihat pada Gambar 4. 


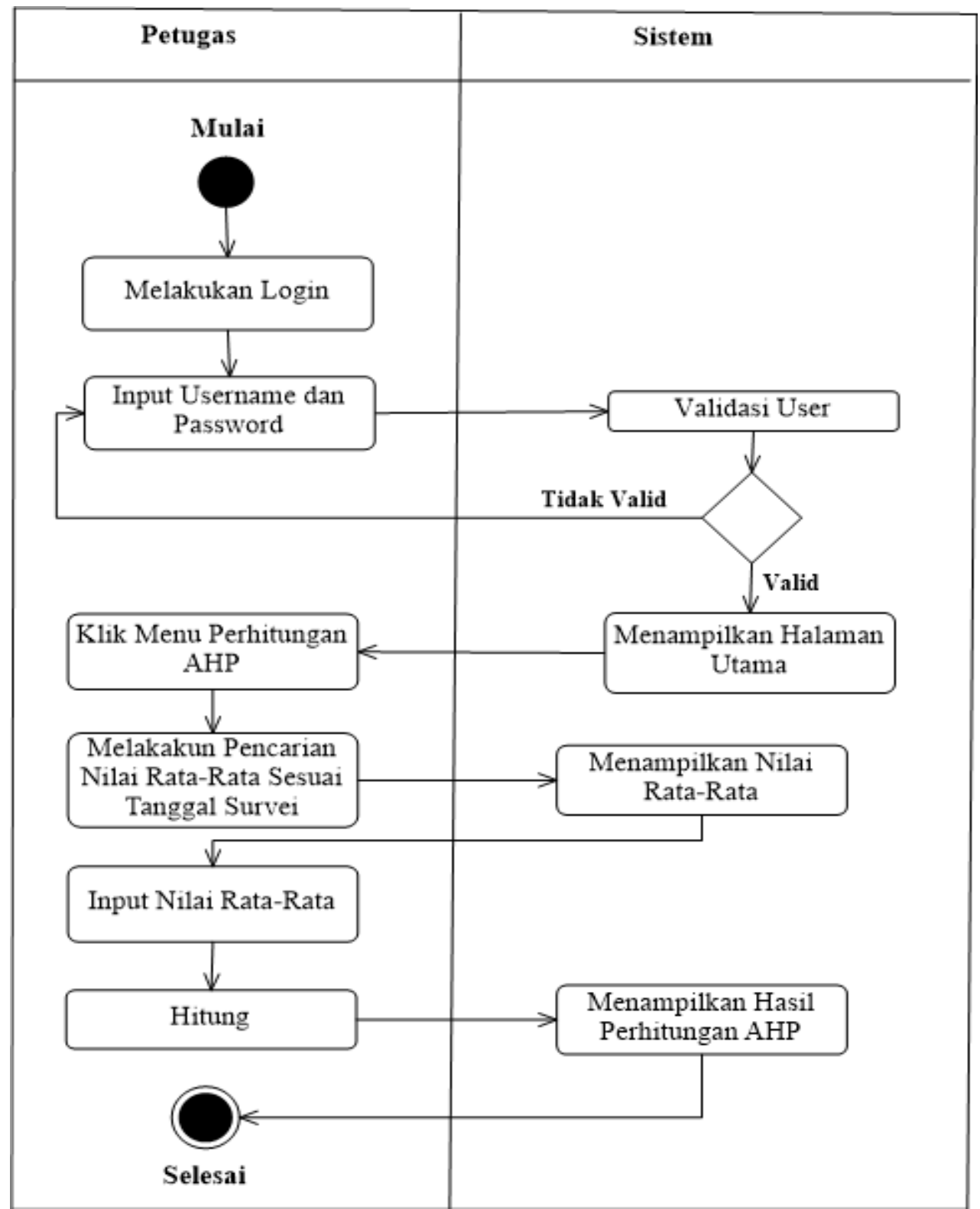

Gambar 4. Activity Diagram Perhitungan AHP

\subsubsection{Class Diagram}

Class diagram adalah diagram yang digunakan untuk menampilkan beberapa kelas yang ada dalam sistem perangkat lunak yang akan dikembangkan. Class Diagram menunjukkan hubungan antar class dalam sistem yang sedang dibangun dan bagaimana mereka saling berkolaborasi untuk mencapai suatu tujuan. Gambar 5 akan menampilkan layout class diagram dari sistem kepuasan masyarakat terhadap pelayanan publik di Kecamatan Talun. 


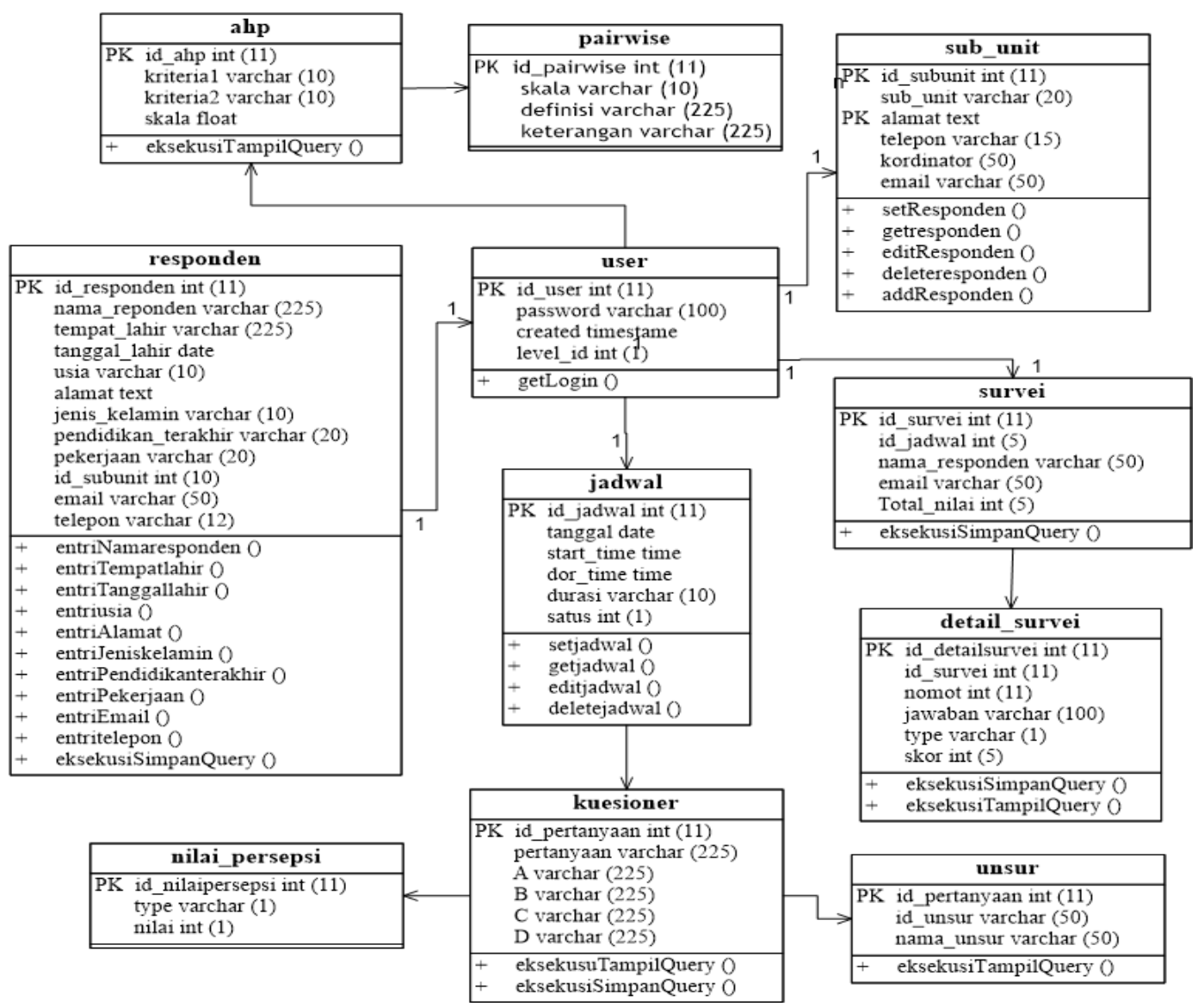

Gambar 5. Class Diagram

\subsubsection{Sequence Diagram}

Sequence Diagram adalah suatu diagram yang menggambarkan interaksi antar objek dan mengindikasikan komunikasi diantara objek-objek tersebut. Berikut Sequence Diagram pada sistem kepuasan masyarakat terhadap pelayanan di Kecamatan Talun.

1. Sequence Diagram Pendaftaran User Masyarakat

Masyarakat melakukan pendaftaran user dengan mengisi form, kemudian sistem akan mengecek kelengkapan, setelah berhasil sistem akan mengarahkan untuk login. Layout-nya dapat dilihat pada Gambar 6. 


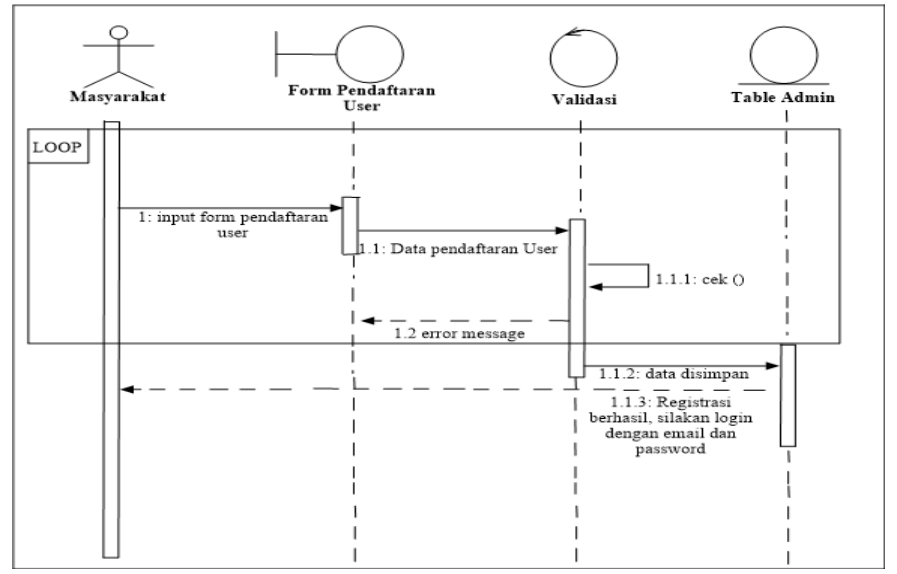

Gambar 6 Sequence Diagram Pendaftaran User

2. Sequence Diagram Login Masyarakat

Masyarakat melakukan pengisian kuesioner. Klik menu kuesioner maka sistem akan menampilkan jadwal pengisian kuesioner, klik jadwal pengisian kuesioner maka sistem akan menampilkan form soal kuesioner, kemudian masyarakat menjawab soal kuesioner, setelah selesai menjawab soal kuesioner masyarakat langsung klik simpan. Layout-nya dapat dilihat pada Gambar 7.

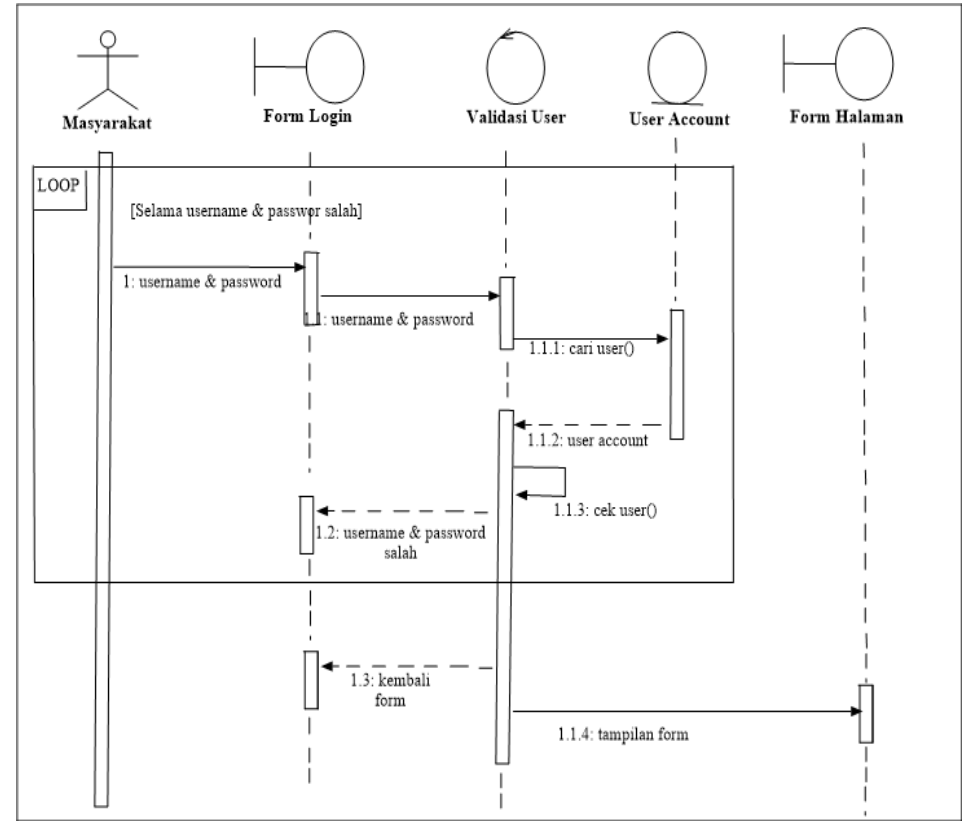

Gambar 7. Sequence Diagram Login Masyarakat

\section{Sequence Diagram Pengisian Kuesioner}

Masyarakat melakukan pengisian kuesioner. Prosesnya adalah klik menu kuesioner maka sistem akan menampilkan jadwal pengisian kuesioner, klik jadwal pengisian kuesioner maka sistem akan menampilkan form soal kuesioner, kemudian masyarakat menjawab soal kuesioner, setelah selesai menjawab soal kuesioner masyarakat langsung klik simpan. Layout-nya dapat dilihat pada Gambar 8. 


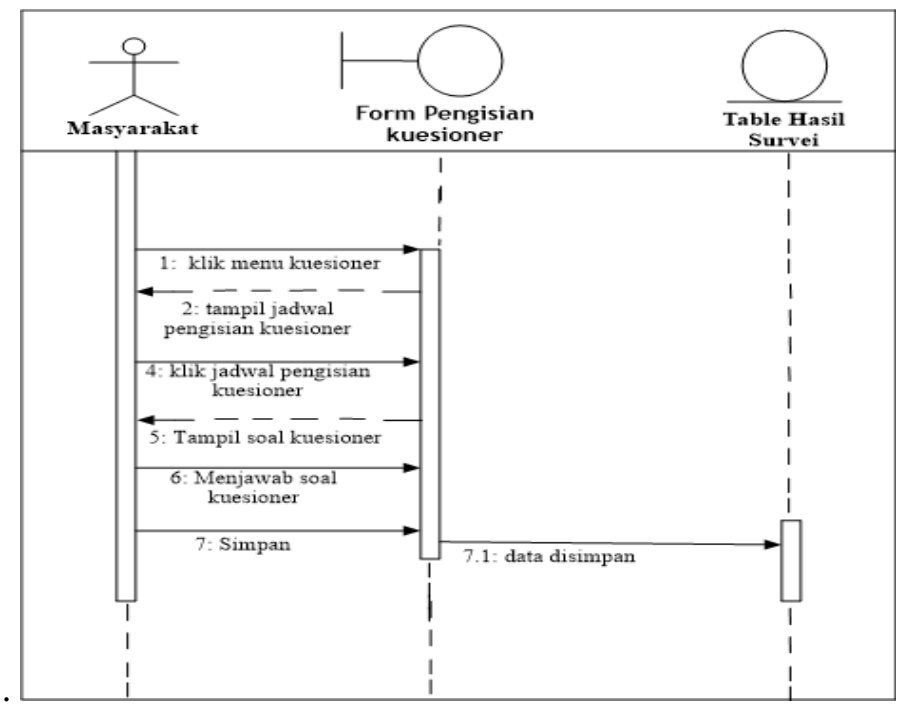

Gambar 8. Sequence Diagram Pengisian Kuesioner

4. Sequence Diagram Login Admin

Admin melakukan proses login, kemudian sistem mencari dan mengecek data user dari database, setelah login berhasil maka sistem akan menampilkan halaman admin. Layout-nya dapat dilihat pada Gambar 9.

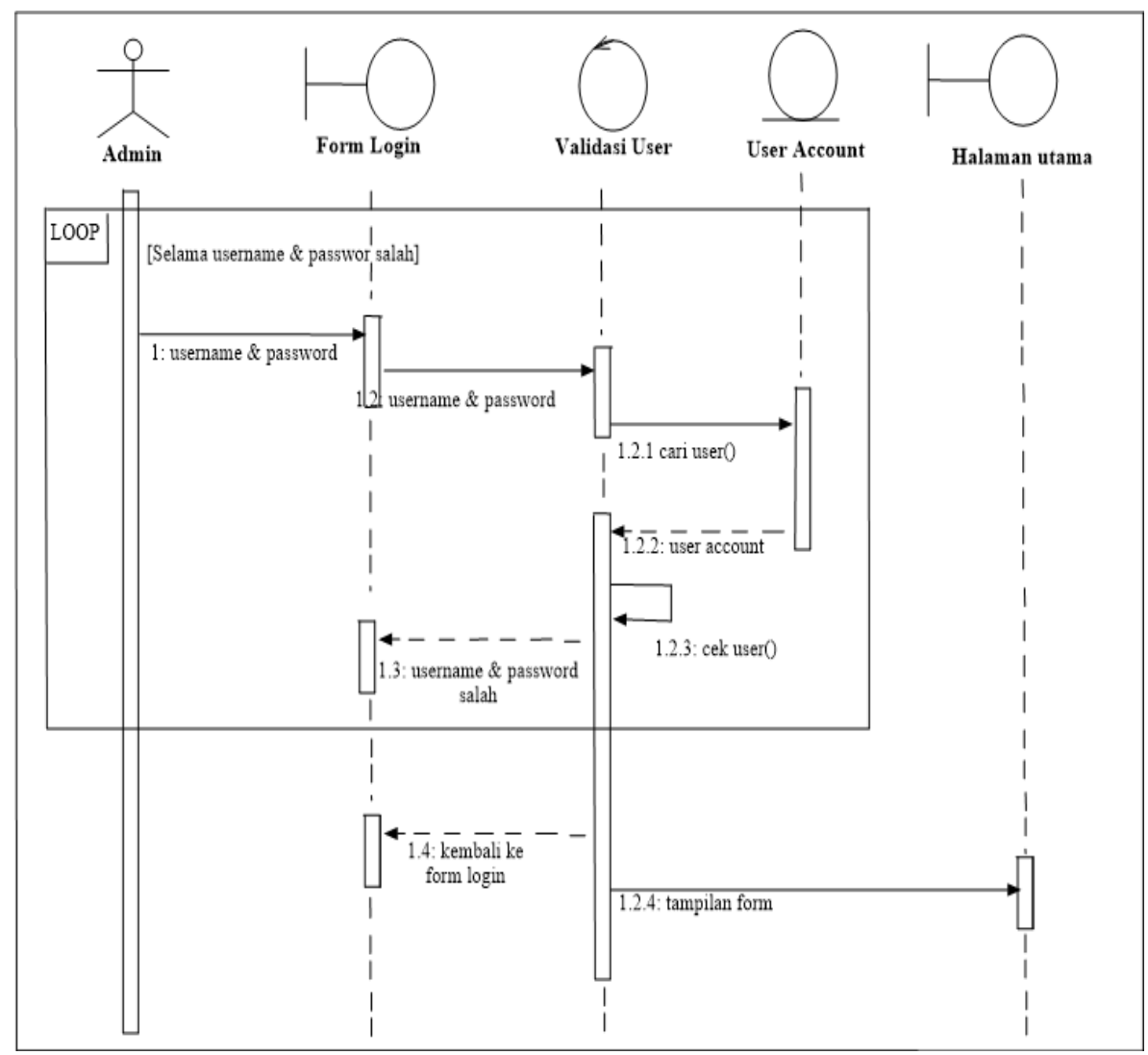

Gambar 9. Sequence Diagram Login Admin 


\section{Sequence Diagram Perhitungan AHP}

Sequence diagram ini menggambarkan petugas klik menu perhitungan AHP, kemudian sistem akan menampilkan form perhitungan AHP, melakukan pencarian nilai rata-rata sesuai tanggal survei, maka sistem akan menampilkan nilai rata-rata, kemudian input nilai rata-rata yang sudah diperbandingkan setiap unsurnya, kemudian klik hitung, maka sistem akan menampilkan hasil perhitungan AHP. Layoutnya dapat dilihat pada Gambar 10.

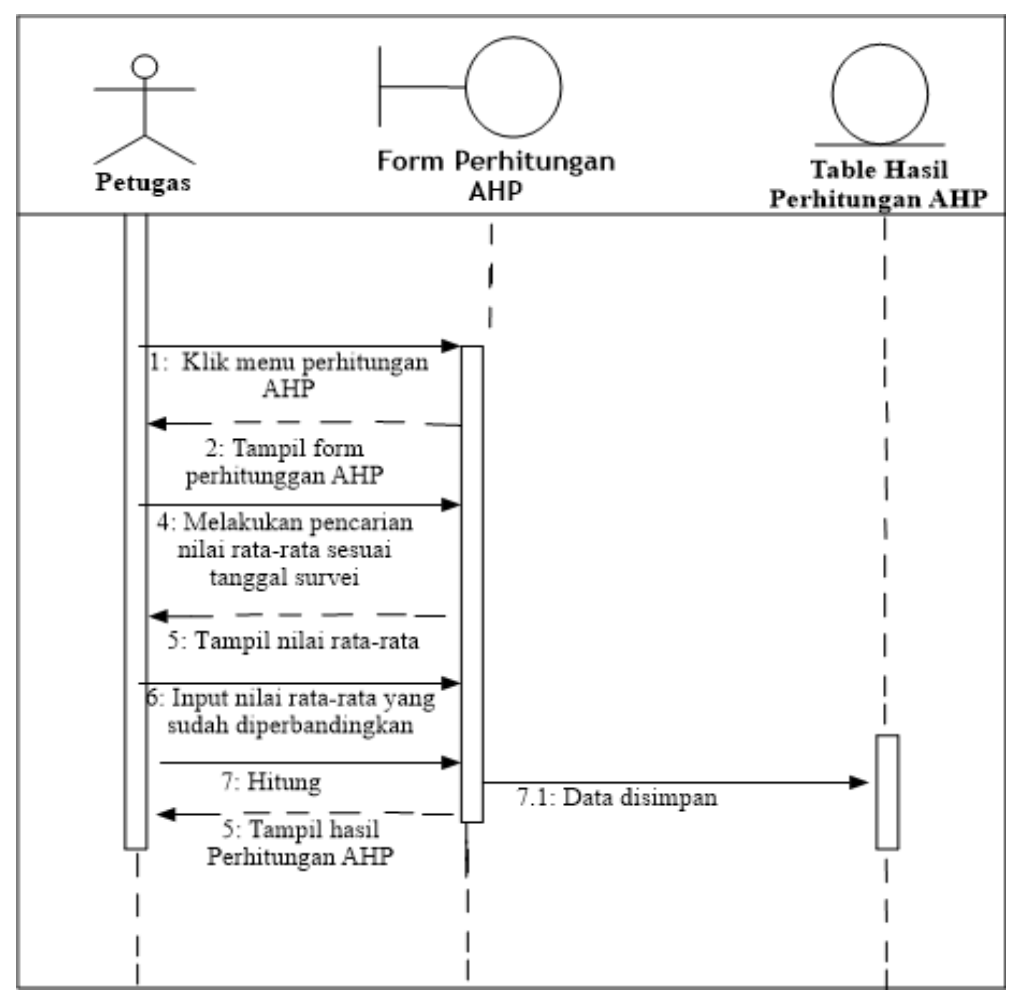

Gambar 10. Sequence Diagram Perhitungan AHP

\subsection{Perhitungan Kuesioner}

Kuesioner yang disebarkan ke masyarakat atau pengunjung di Kecamatan Talun sebanyak 34 orang. Data hasil kuesioner yang disebarkan dapat dilihat pada Tabel 2.

Tabel 2. Data Jawaban Kuesioner

\begin{tabular}{|c|l|c|c|c|c|}
\hline \multirow{2}{*}{ NO } & \multirow{2}{*}{ UNSUR PELAYANAN } & \multicolumn{4}{c|}{ JAWABAN } \\
\cline { 3 - 6 } & & $\mathbf{A ~ ( 1 )}$ & $\mathbf{B}(\mathbf{2})$ & $\mathbf{C}(\mathbf{3})$ & D (4) \\
\hline 1 & Prosedur Pelayanan & 3 & 14 & 14 & 3 \\
\hline 2 & Persyaratan Pelayanan & 5 & 10 & 18 & 1 \\
\hline 3 & Kejelasan Petugas Pelayanan & 6 & 13 & 14 & 1 \\
\hline 4 & Kedisiplinan Petugas & 3 & 11 & 14 & 6 \\
\hline 5 & Tanggung jawab Petugas & 4 & 17 & 10 & 3 \\
\hline 6 & Kecepatan Pelayanan & 8 & 16 & 3 & 7 \\
\hline 7 & Keadilan Mendapatkan Pelayanan & 1 & 17 & 16 & - \\
\hline 8 & Kesopanan dan Keramahan Petugas & 2 & 6 & 22 & 4 \\
\hline
\end{tabular}




\begin{tabular}{|c|l|c|c|c|c|}
\hline 9 & Kewajaran Biaya Pelayanan & 4 & 10 & 16 & 4 \\
\hline 10 & Kesesuaian Biaya Pelayanan & 4 & 19 & 4 & 7 \\
\hline 11 & Ketepatan Jadwal Pelayanan & 7 & 20 & 3 & 4 \\
\hline 12 & Kenyamanan Lingkungan & 6 & 8 & 15 & 5 \\
\hline 13 & Keamanan Pelayanan & 3 & 12 & 18 & 1 \\
\hline 14 & Kemampuan Petugas Pelayanan & 5 & 7 & 17 & 5 \\
\hline
\end{tabular}

Selanjutnya, hasil nilai Konversi Indeks Kepuasan Masyarakat (IKM) Kecamatan Talun, Kabupaten Cirebon, disesuaikan dengan kategorisasi mutu pelayanan berdasarkan indeks yang ditunjukkan pada Tabel 3.

Tabel 3. Kategorisasi Mutu Pelayanan

\begin{tabular}{|c|c|c|c|}
\hline $\begin{array}{c}\text { Nilai Interval } \\
\text { IKM }\end{array}$ & $\begin{array}{c}\text { Nilai Interval } \\
\text { Konversi IKM }\end{array}$ & $\begin{array}{c}\text { Mutu } \\
\text { Pelayanan }\end{array}$ & $\begin{array}{c}\text { Kinerja Unit } \\
\text { Pelayanan }\end{array}$ \\
\hline $1,00-1,75$ & $25,00-43,75$ & $\mathrm{D}$ & TIDAK BAIK \\
\hline $1,76-2,50$ & $43,76-62,50$ & $\mathrm{C}$ & KURANG BAIK \\
\hline $2,51-3,25$ & $62,51-81,25$ & $\mathrm{~B}$ & BAIK \\
\hline $3,26-4,00$ & $81,26-100,00$ & $\mathrm{~A}$ & SANGAT BAIK \\
\hline
\end{tabular}

Berdasarkan kategorisasi mutu pelayanan pada tabel di atas, maka Kecamatan Talun Kabupaten Cirebon memperoleh hasil Konversi IKM sebesar 50,38. Kinerja unit pelayanan Kantor Kecamatan Talun berada dalam mutu pelayanan "C" dengan kategori "KURANG BAIK".

\subsection{Perhitungan AHP}

\subsubsection{Nilai Rata-Rata}

Berdasarkan data hasil survei dari responden pada Tabel 2., maka diperoleh nilai rata-rata seperti terlihat pada Tabel 4.

Tabel 4. Nilai Rata-Rata

\begin{tabular}{|c|c|c|c|c|c|c|c|c|c|c|c|c|c|}
\hline U01 & U02 & U03 & U04 & U05 & U06 & U07 & U08 & U09 & U10 & U11 & U12 & U13 & U14 \\
\hline 2.059 & 2.176 & 2 & 1.882 & 1.882 & 1.176 & 2.441 & 2.765 & 2 & 1.471 & 1.647 & 2.382 & 2.412 & 2.088 \\
\hline
\end{tabular}

\subsubsection{Matriks Pairwise Comparison}

Data nilai rata-rata pada Tabel 4. diperoleh dari pengisian kuesioner masyarakat, jawaban setiap soalnya dijumlahkan, dengan keterangan jumlah per-soal dikalikan dengan nilai bobot per-jawaban, kemudian di bagi dengan jumlah responden. Kemudian dibuatlah matriks perbandingan dari setiap unsur kemudian dijumlahkan dengan setiap nilai pada sel kolom. 
Tabel 5 Matriks Pairwise Comparison untuk Semua Kriteria

\begin{tabular}{|c|c|c|c|c|c|c|c|c|c|c|c|c|c|c|}
\hline UNSUR & U01 & U02 & U03 & U04 & U05 & U06 & U07 & U08 & U09 & U10 & U11 & U12 & U13 & U14 \\
\hline U01 & 1 & 1 & 1 & 1 & 1 & $1 / 2$ & 1 & $1 / 2$ & 1 & $1 / 2$ & 1 & 1 & 1 & 1 \\
\hline U02 & 1 & 1 & 1 & 1 & 1 & $1 / 2$ & 1 & $1 / 2$ & 1 & $1 / 2$ & 1 & 1 & 1 & 1 \\
\hline U03 & 1 & 1 & 1 & 1 & 1 & $1 / 2$ & 1 & $1 / 2$ & 1 & $1 / 2$ & 1 & 1 & 1 & 1 \\
\hline U04 & 1 & 1 & 1 & 1 & 1 & $1 / 2$ & 1 & $1 / 2$ & 1 & $1 / 2$ & 1 & 1 & 1 & 1 \\
\hline U05 & 1 & 1 & 1 & 1 & 1 & $1 / 2$ & 1 & $1 / 2$ & 1 & $1 / 2$ & 1 & $1 / 2$ & 1 & 1 \\
\hline U06 & 2 & 2 & 2 & 2 & 2 & 1 & $1 / 2$ & $1 / 3$ & $1 / 2$ & 1 & $1 / 2$ & $1 / 2$ & $1 / 2$ & $1 / 2$ \\
\hline U07 & 1 & 1 & 1 & 1 & 1 & 2 & 1 & $1 / 2$ & 1 & $1 / 2$ & 1 & 1 & 1 & 1 \\
\hline U08 & 2 & 2 & 2 & 2 & 2 & 3 & 2 & 1 & $1 / 2$ & $1 / 3$ & $1 / 2$ & $1 / 2$ & $1 / 2$ & $1 / 2$ \\
\hline U09 & 1 & 1 & 1 & 1 & 1 & 2 & 1 & 2 & 1 & $1 / 2$ & 1 & 1 & 1 & 1 \\
\hline U10 & 2 & 2 & 2 & 2 & 2 & 1 & 2 & 3 & 2 & 1 & $1 / 2$ & $1 / 2$ & $1 / 2$ & $1 / 2$ \\
\hline U11 & 1 & 1 & 1 & 1 & 1 & 2 & 1 & 2 & 1 & 2 & 1 & 1 & 1 & 1 \\
\hline U12 & 1 & 1 & 1 & 1 & 2 & 2 & 1 & 2 & 1 & 2 & 1 & 1 & 1 & 1 \\
\hline U13 & 1 & 1 & 1 & 1 & 1 & 2 & 1 & 2 & 1 & 2 & 1 & 1 & 1 & 1 \\
\hline U14 & 1 & 1 & 1 & 1 & 1 & 2 & 1 & 2 & 1 & 2 & 1 & 1 & 1 & 1 \\
\hline
\end{tabular}

Masukkan data nilai rata-rata dengan keterangan, jika nilai rata-rata 2,833 maka yang diambil 3, jika nilai rata-rata 2,581 maka yang diambil 2 atau 3, jika nilai rata 2,33 maka yang diambil 2, kemudian diperbandingan setiap unsurnya jika kedua unsur sama maka nilainya satu, misalkan perbandingan baris U01 dengan kolom U01 berarti sama maka nilainya 1, perbandingan baris U01 dengan kolom U02 dengan keterangan $\mathrm{U} 01=2$ dan $\mathrm{U} 04=1$ jaraknya berselisih 1 maka nilai perbandingannya yaitu $1 /(1+1)$ $=1 / 2$ dan untuk baris U02 perbandingan dengan kolom U01 maka kebalikannya yaitu $(1+1) / 1=2$ dan seterusnya.

Tabel 6 Matriks Faktor Pembobotan Hierarki untuk Semua Kriteria

\begin{tabular}{|c|c|c|c|c|c|c|c|c|c|c|c|c|c|c|}
\hline UNSUR & U01 & U02 & U03 & U04 & U05 & U06 & U07 & U08 & U09 & U10 & U11 & U12 & U13 & U14 \\
\hline U01 & 1 & 1 & 1 & 1 & 1 & 0.5 & 1 & 0.5 & 1 & 0.5 & 1 & 1 & 1 & 1 \\
\hline U02 & 1 & 1 & 1 & 1 & 1 & 0.5 & 1 & 0.5 & 1 & 0.5 & 1 & 1 & 1 & 1 \\
\hline U03 & 1 & 1 & 1 & 1 & 1 & 0.5 & 1 & 0.5 & 1 & 0.5 & 1 & 1 & 1 & 1 \\
\hline U04 & 1 & 1 & 1 & 1 & 1 & 0.5 & 1 & 0.5 & 1 & 0.5 & 1 & 1 & 1 & 1 \\
\hline U05 & 1 & 1 & 1 & 1 & 1 & 0.5 & 1 & 0.5 & 1 & 0.5 & 1 & 0.5 & 1 & 1 \\
\hline U06 & 2 & 2 & 2 & 2 & 2 & 1 & 0.5 & 0.3333 & 0.5 & 1 & 0.5 & 0.5 & 0.5 & 0.5 \\
\hline U07 & 1 & 1 & 1 & 1 & 1 & 2 & 1 & 0.5 & 1 & 0.25 & 1 & 1 & 1 & 1 \\
\hline $\mathbf{U 0 8}$ & 2 & 2 & 2 & 2 & 2 & 3 & 2 & 1 & 0.5 & 0.33333 & 0.5 & 0.5 & 0.5 & 0.5 \\
\hline $\mathbf{U 0 9}$ & 1 & 1 & 1 & 1 & 1 & 2 & 1 & 2 & 1 & 0.5 & 1 & 1 & 1 & 1 \\
\hline $\mathbf{U 1 0}$ & 2 & 2 & 2 & 2 & 2 & 1 & 2 & 3 & 2 & 1 & 0.5 & 0.5 & 0.5 & 0.5 \\
\hline $\mathbf{U 1 1}$ & 1 & 1 & 1 & 1 & 1 & 2 & 1 & 2 & 1 & 2 & 1 & 1 & 1 & 1 \\
\hline $\mathbf{U 1 2}$ & 1 & 1 & 1 & 1 & 2 & 2 & 1 & 2 & 1 & 2 & 1 & 1 & 1 & 1 \\
\hline $\mathbf{U 1 3}$ & 1 & 1 & 1 & 1 & 1 & 2 & 1 & 2 & 1 & 2 & 1 & 1 & 1 & 1 \\
\hline $\mathbf{U 1 4}$ & 1 & 1 & 1 & 1 & 1 & 2 & 1 & 2 & 1 & 2 & 1 & 1 & 1 & 1 \\
\hline$\Sigma$ & 17 & 17 & 17 & 17 & 18 & 19.5 & 15.5 & 17.333 & 14 & 13.5833 & 12.5 & 12 & 12.5 & 12.5 \\
\hline
\end{tabular}

Berdasarkan nilai yang diperoleh dari Tabel 6., selanjutnya setiap nilai sel kolom matriks perbandingan dibagi dengan total jumlah sel kolom matriks perbandingan, kemudian setiap sel kolom dijumlahkan dan setiap sel baris dijumlahkan. Misalkan jumlah sel kolom adalah 1 dan jumlah sel kolom 17, maka 1 $/ 17=0,059$. Hasilnya dapat dilihat pada Tabel 7 . 
Tabel 7 Matriks Faktor Pembobotan Hierarki untuk semua kriteria yang Dinormalkan

\begin{tabular}{|c|c|c|c|c|c|c|c|c|c|c|c|c|c|c|c|}
\hline UNSUR & U01 & U02 & U03 & U04 & U05 & U06 & U07 & U08 & U09 & U10 & U11 & U12 & U13 & U14 & Jumlah \\
\hline U01 & 0.059 & 0.059 & 0.0588 & 0.0588 & 0.0556 & 0.0256 & 0.0645 & 0.0288 & 0.0714 & 0.0368 & 0.08 & 0.083 & 0.08 & 0.08 & 0.8412 \\
\hline U02 & 0.059 & 0.059 & 0.0588 & 0.0588 & 0.0556 & 0.0256 & 0.0645 & 0.0288 & 0.0714 & 0.0368 & 0.08 & 0.083 & 0.08 & 0.08 & 0.8412 \\
\hline U03 & 0.059 & 0.059 & 0.0588 & 0.0588 & 0.0556 & 0.0256 & 0.0645 & 0.0288 & 0.0714 & 0.0368 & 0.08 & 0.083 & 0.08 & 0.08 & 0.8412 \\
\hline U04 & 0.059 & 0.059 & 0.0588 & 0.0588 & 0.0556 & 0.0256 & 0.0645 & 0.0288 & 0.0714 & 0.0368 & 0.08 & 0.083 & 0.08 & 0.08 & 0.8412 \\
\hline U05 & 0.059 & 0.059 & 0.0588 & 0.0588 & 0.0556 & 0.0256 & 0.0645 & 0.0288 & 0.0714 & 0.0368 & 0.08 & 0.042 & 0.08 & 0.08 & 0.7996 \\
\hline U06 & 0.118 & 0.118 & 0.1176 & 0.1176 & 0.1111 & 0.0513 & 0.0323 & 0.0192 & 0.0357 & 0.0736 & 0.04 & 0.042 & 0.04 & 0.04 & 0.9553 \\
\hline U07 & 0.059 & 0.059 & 0.0588 & 0.0588 & 0.0556 & 0.1026 & 0.0645 & 0.0288 & 0.0714 & 0.0184 & 0.08 & 0.083 & 0.08 & 0.08 & 0.8998 \\
\hline U08 & 0.118 & 0.118 & 0.1176 & 0.1176 & 0.1111 & 0.1538 & 0.129 & 0.0577 & 0.0357 & 0.0245 & 0.04 & 0.042 & 0.04 & 0.04 & 1.1439 \\
\hline U09 & 0.059 & 0.059 & 0.0588 & 0.0588 & 0.0556 & 0.1026 & 0.0645 & 0.1154 & 0.0714 & 0.0368 & 0.08 & 0.083 & .08 & 0.08 & 1.0048 \\
\hline U10 & 0.118 & 0.118 & 0.1176 & 0.1176 & 0.1111 & 0.0513 & 0.129 & 0.1731 & 0.1429 & 0.0736 & 0.04 & 0.042 & 0.04 & 0.04 & 1.3131 \\
\hline U11 & 0.059 & 0.059 & 0.0588 & 0.0588 & 0.0556 & 0.1026 & 0.0645 & 0.1154 & 0.0714 & 0.1472 & 0.08 & 0.083 & 0.08 & 0.08 & 1.1152 \\
\hline U12 & 0.059 & 0.059 & 0.0588 & 0.0588 & 0.1111 & 0.1026 & 0.0645 & 0.1154 & 0.0714 & 0.1472 & 0.08 & 0.083 & 0.08 & 0.08 & 1.1707 \\
\hline U13 & 0.059 & 0.059 & 0.0588 & 0.0588 & 0.0556 & 0.1026 & 0.0645 & 0.1154 & 0.0714 & 0.1472 & 0.08 & 0.083 & 0.08 & 0.08 & 1.1152 \\
\hline U14 & 0.059 & 0.059 & 0.0588 & 0.0588 & 0.0556 & 0.1026 & 0.0645 & 0.1154 & 0.0714 & 0.1472 & 0.08 & 0.083 & 0.08 & 0.08 & 1.1152 \\
\hline Jumlah & 1 & 1 & 0.9996 & 0.9996 & 1.0004 & 1 & 0.9998 & 0.9998 & 0.9997 & 0.9997 & 1 & 1 & 1 & 1 & 13.9976 \\
\hline
\end{tabular}

\subsubsection{Menghitung Bobot Vektor Eigen}

Proses selanjutnya adalah menghitung bobot vektor eigen. Berdasarkan data yang ada di Tabel 7. dengan setiap jumlah sel baris di bagi dengan jumlah hasil penjumlahan dari setiap sel kolom. Misalkan jumlah sel baris adalah 0.8412 dan jumlah sel kolom 13.9976, maka 0,8412 / 13,9976 =0,0601 =0,06 (untuk kolom vektor eigen baris U01). Hasilnya dapat dilihat pada Tabel 8.

Tabel 8. Hasil Pencarian Bobot Vektor Eigen

\begin{tabular}{|c|c|c|c|c|c|c|c|c|c|c|c|c|c|c|c|}
\hline UNSUR & U01 & U02 & U03 & U04 & U05 & U06 & U07 & U08 & U09 & U10 & U11 & U12 & U13 & U14 & $\begin{array}{c}\text { vektor } \\
\text { eigen }\end{array}$ \\
\hline U01 & 0.059 & 0.059 & 0.0588 & 0.0588 & 0.0556 & 0.0256 & 0.0645 & 0.0288 & 0.0714 & 0.0368 & 0.08 & 0.083 & 0.08 & 0.08 & 0.0601 \\
\hline U02 & 0.059 & 0.059 & 0.0588 & 0.0588 & 0.0556 & 0.0256 & 0.0645 & 0.0288 & 0.0714 & 0.0368 & 0.08 & 0.083 & 0.08 & 0.08 & 0.0601 \\
\hline U03 & 0.059 & 0.059 & 0.0588 & 0.0588 & 0.0556 & 0.0256 & 0.0645 & 0.0288 & 0.0714 & 0.0368 & 0.08 & 0.083 & 0.08 & 0.08 & 0.0601 \\
\hline U04 & 0.059 & 0.059 & 0.0588 & 0.0588 & 0.0556 & 0.0256 & 0.0645 & 0.0288 & 0.0714 & 0.0368 & 0.08 & 0.083 & 0.08 & 0.08 & 0.0601 \\
\hline U05 & 0.059 & 0.059 & 0.0588 & 0.0588 & 0.0556 & 0.0256 & 0.0645 & 0.0288 & 0.0714 & 0.0368 & 0.08 & 0.042 & 0.08 & 0.08 & 0.0571 \\
\hline U06 & 0.118 & 0.118 & 0.1176 & 0.1176 & 0.1111 & 0.0513 & 0.0323 & 0.0192 & 0.0357 & 0.0736 & 0.04 & 0.042 & 0.04 & 0.04 & 0.0682 \\
\hline U07 & 0.059 & 0.059 & 0.0588 & 0.0588 & 0.0556 & 0.1026 & 0.0645 & 0.0288 & 0.0714 & 0.0184 & 0.08 & 0.083 & 0.08 & 0.08 & 0.0643 \\
\hline U08 & 0.118 & 0.118 & 0.1176 & 0.1176 & 0.1111 & 0.1538 & 0.129 & 0.0577 & 0.0357 & 0.0245 & 0.04 & 0.042 & 0.04 & 0.04 & 0.0817 \\
\hline U09 & 0.059 & 0.059 & 0.0588 & 0.0588 & 0.0556 & 0.1026 & 0.0645 & 0.1154 & 0.0714 & 0.0368 & 0.08 & 0.083 & .08 & 0.08 & 0.0718 \\
\hline U10 & 0.118 & 0.118 & 0.1176 & 0.1176 & 0.1111 & 0.0513 & 0.129 & 0.1731 & 0.1429 & 0.0736 & 0.04 & 0.042 & 0.04 & 0.04 & 0.0938 \\
\hline U11 & 0.059 & 0.059 & 0.0588 & 0.0588 & 0.0556 & 0.1026 & 0.0645 & 0.1154 & 0.0714 & 0.1472 & 0.08 & 0.083 & 0.08 & 0.08 & 0.0797 \\
\hline U12 & 0.059 & 0.059 & 0.0588 & 0.0588 & 0.1111 & 0.1026 & 0.0645 & 0.1154 & 0.0714 & 0.1472 & 0.08 & 0.083 & 0.08 & 0.08 & 0.0836 \\
\hline U13 & 0.059 & 0.059 & 0.0588 & 0.0588 & 0.0556 & 0.1026 & 0.0645 & 0.1154 & 0.0714 & 0.1472 & 0.08 & 0.083 & 0.08 & 0.08 & 0.0797 \\
\hline U14 & 0.059 & 0.059 & 0.0588 & 0.0588 & 0.0556 & 0.1026 & 0.0645 & 0.1154 & 0.0714 & 0.1472 & 0.08 & 0.083 & 0.08 & 0.08 & 0.0797 \\
\hline Jumlah & 1 & 1 & 0.9996 & 0.9996 & 1.0004 & 1 & 0.9998 & 0.9998 & 0.9997 & 0.9997 & 1 & 1 & 1 & 1 & \\
\hline
\end{tabular}

\subsubsection{Menghitung Eigen Maksimum ( $\lambda$ maksimum)}

Nilai eigen maksimum didapat dengan menjumlahkan hasil perkalian jumlah kolom dengan vektor eigen. Nilai eigen maksimum yang diperoleh dapat dilihat pada Tabel 9. 
Tabel 9. Perhitungan Eigen Maksimum

\begin{tabular}{|c|c|c|r|}
\hline UNSUR & $\sum$ Eigen & Vektor Eigen & \multicolumn{1}{|c|}{ Hasil Perkalian } \\
\hline U01 & 17 & 0.060096016 & 1.02163228 \\
\hline U02 & 17 & 0.060096016 & 1.02163228 \\
\hline U03 & 17 & 0.060096016 & 1.02163228 \\
\hline U04 & 17 & 0.060096016 & 1.02163228 \\
\hline U05 & 18 & 0.057124078 & 1.028233411 \\
\hline U06 & 19.5 & 0.068247414 & 1.33082457 \\
\hline U07 & 15.5 & 0.064282448 & 0.996377951 \\
\hline U08 & 17.333 & 0.081721152 & 1.416472731 \\
\hline U09 & 14 & 0.071783734 & 1.004972281 \\
\hline U10 & 13.583 & 0.093808939 & 1.274206814 \\
\hline U11 & 12.5 & 0.079670801 & 0.995885009 \\
\hline U12 & 12 & 0.083635766 & 1.003629194 \\
\hline U13 & 12.5 & 0.079670801 & 0.995885009 \\
\hline U14 & 12.5 & 0.079670801 & 0.995885009 \\
\hline
\end{tabular}

\subsubsection{Menghitung Rasio Konsistensi (CR)}

Tabel 10 Nilai Indeks Acak (Tabel Skala Saaty)

\begin{tabular}{|c|c|c|c|c|c|c|c|c|c|c|c|c|c|c|c|}
\hline $\mathbf{N}$ & $\mathbf{1}$ & $\mathbf{2}$ & $\mathbf{3}$ & $\mathbf{4}$ & $\mathbf{5}$ & $\mathbf{6}$ & $\mathbf{7}$ & $\mathbf{8}$ & $\mathbf{9}$ & $\mathbf{1 0}$ & $\mathbf{1 1}$ & $\mathbf{1 2}$ & $\mathbf{1 3}$ & $\mathbf{1 4}$ & $\mathbf{1 5}$ \\
\hline $\mathrm{RI}$ & 0 & 0 & 0.58 & 0.9 & 1.12 & 1.24 & 1.32 & 1.41 & 1.45 & 1.49 & 1.51 & 1.48 & 1.56 & 1.57 & 1.59 \\
\hline
\end{tabular}

Karena $\mathrm{n}=14$, maka $\mathrm{RI}=1,57$ (tabel skala saaty) maka:

$$
\begin{aligned}
C R & =\frac{C I}{R I} \\
& =0,087=0,055<0,100 \\
1,57 &
\end{aligned}
$$

Karena nilai CR $<0,100$ berarti preferensi penilaian adalah konsisten.

Dari perhitungan tabel dia atas diperoleh hasil, sebagai berikut:

Tabel 8. Nilai Akhir

\begin{tabular}{|c|c|}
\hline UNSUR & Vektor eigen \\
\hline U10 & 0.093808939 \\
\hline U12 & 0.083635766 \\
\hline U08 & 0.081721152 \\
\hline U11 & 0.079670801 \\
\hline U13 & 0.079670801 \\
\hline U14 & 0.079670801 \\
\hline U09 & 0.071783734 \\
\hline U06 & 0.068247414 \\
\hline U07 & 0.064282448 \\
\hline U01 & 0.060096016 \\
\hline U02 & 0.060096016 \\
\hline U03 & 0.060096016 \\
\hline U04 & 0.060096016 \\
\hline
\end{tabular}




\begin{tabular}{|l|r|}
\hline U05 & 0.057124078 \\
\hline
\end{tabular}

Dari perhitungan data diatas menunjukkan unsur U10 yang paling tinggi prioritasnya, tentang kepuasan masyarakat terhadap pelayanan yang diberikan oleh petugas Kecamatan Talun.

\section{IMPLEMENTASI SISTEM}

Tahap implementasi sistem merupakan proses untuk menilai kesiapan sistem pada saat diterapkan pada lingkungan yang sesuai dengan perancangan yang telah dilakukan.

\section{Tampilan Form Pengguna (Masyarakat)}

a. Form Login (Halaman Utama)

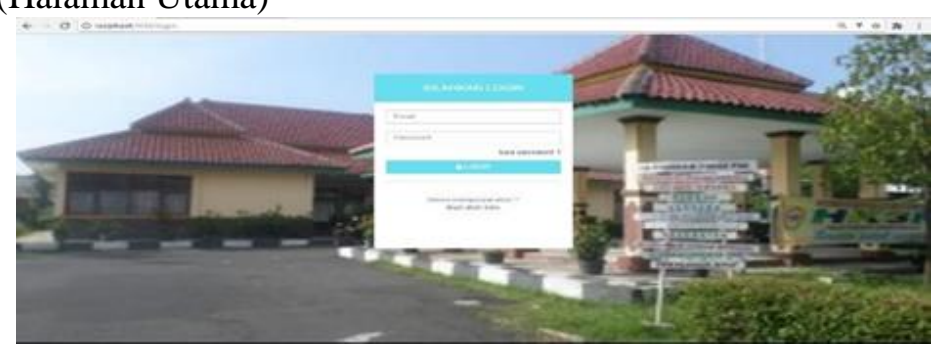

\section{Keterangan:}

Gambar 11. Form Login (Halaman Utama)

Halaman ini adalah halaman utama pada aplikasi sistem kepuasan masyarakat terhadap pelayanan publik di Kecamatan Talun.

b. Halaman User (Masyarakat)

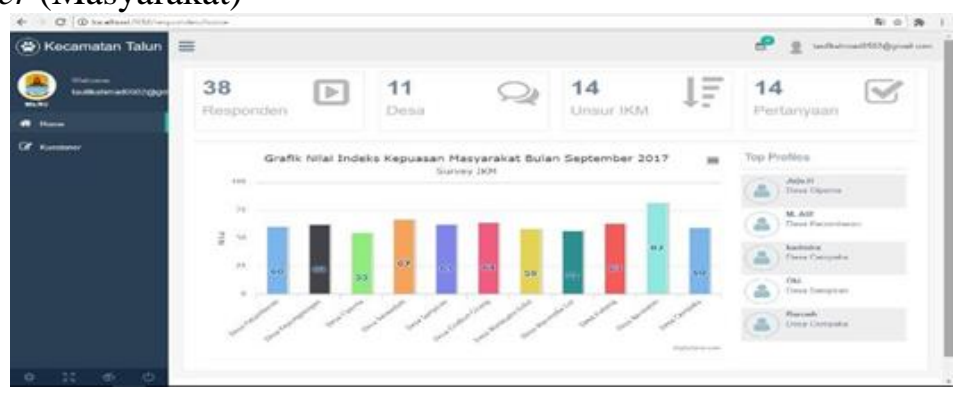

Gambar 12. Halaman User (masyarakat)

\section{Keterangan:}

Halaman ini adalah halaman pengguna atau masyarakat yang sudah melakukan akses login dengan terdapat menu untuk pengisian kuesioner.

Halaman Pengisian Kuesioner

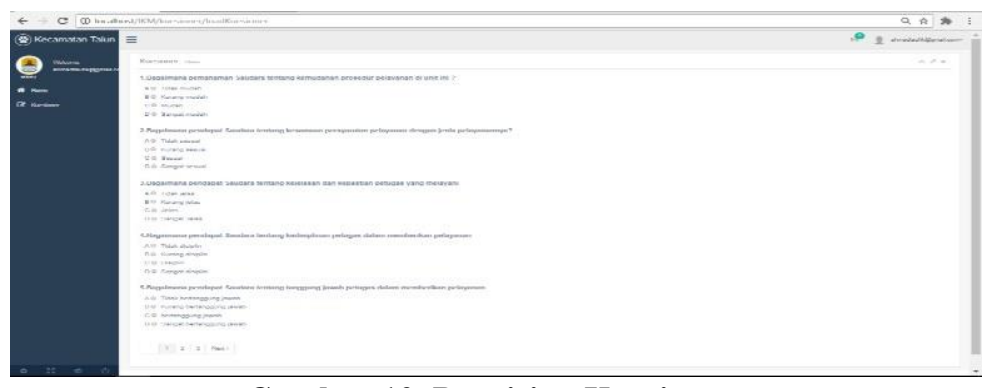

Gambar 12. Pengisian Kuesioner

\section{Keterangan:}

Halaman ini adalah halaman soal kuesioner untuk pengguna atau masyarakat yang akan melakukan pengisian kuesioner. 


\section{Tampilan Form Petugas Kecamatan (Admin)}

a. Halaman Penghitungan AHP

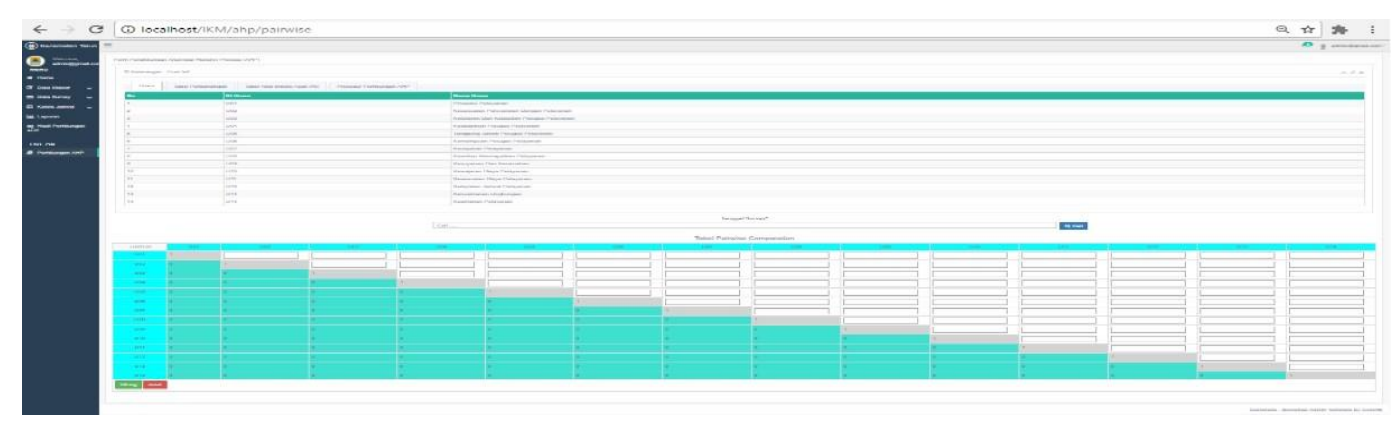

Gambar 13. Perhitungan AHP (Admin)

\section{Keterangan:}

Halaman ini adalah halaman admin untuk melakukan perhitungan AHP dengan menginputkan nilai rata- rata yang sudah di perbandingkan.

b. Laporan hasil penilaian masyarakat

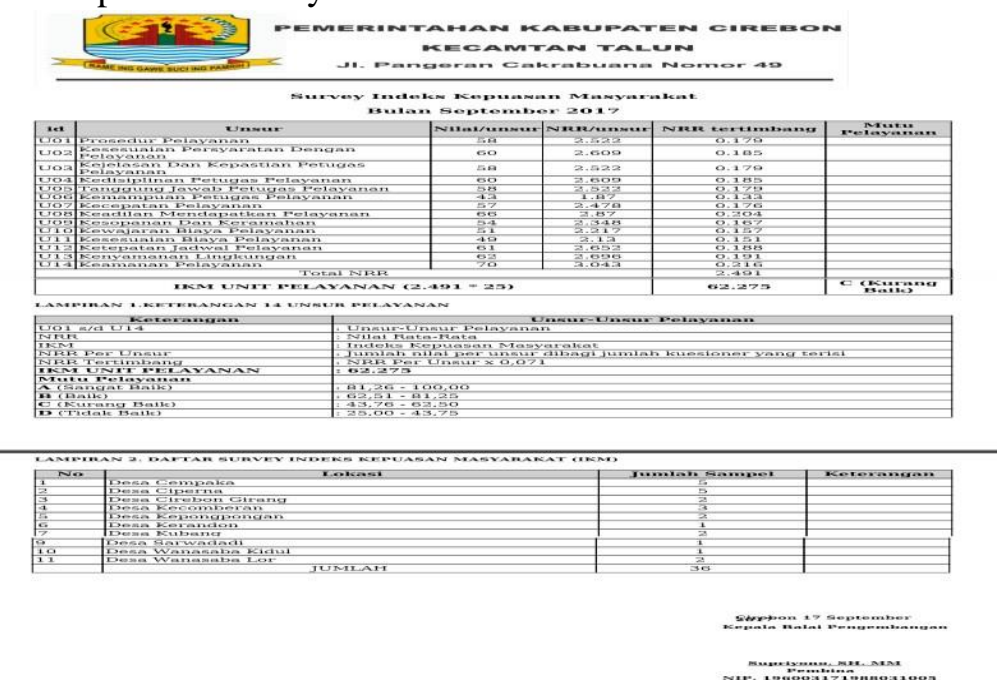

Gambar 14. Laporan Hasil Penilaian Masyarakat

\section{Keterangan:}

Laporan ini adalah laporan tingkat kepuasan masyarakat terhadap pelayanan publik di Kecamatan Talun dari hasil pengisian kuesioner. 


\section{KESIMPULAN}

\subsection{Kesimpulan}

Dari hasil analisis dan implementasi sistem mengenai penilaian pelayanan dengan menggunakan metode Analytical Hierarchy Process (AHP), didapat beberapa kesimpulan yang diperoleh sebagai berikut:

1. Metode AHP merupakan salah satu metode sistem penunjang keputusan yang mampu membantu penyelesaian permasalahan penilaian kinerja pelayanan publik di Kecamatan talun dengan akurasi tinggi. Hasil dari perhitungan AHP yang diperoleh yaitu nilai eigen vektor.

2. Dari hasil perhitungan AHP dapat diketahui nilai kepuasan masyarakat dari pengisian kuesioner, sehingga nilai yang diperoleh dapat membantu Camat dalam menentukan kebijakan terutama dalam meningkatkan pelayanan publik.

3. Dengan aplikasi ini masyarakat Kecamatan Talun dapat dengan mudah memberikan penilaian terhadap pelayanan publik dimana pun dan kapan pun dengan melakukan pengisian kuesioner secara online.

\section{DAFTAR RUJUKAN}

Fowler. (2005). UML Distilled, Panduam Singkat Bahasa Pemodelan Objek Standar, Edisi 3, Penerbit Andi Yogyakarta.,

Kusrini. (2007). Konsep dan Aplikasi Sistem Pendukung Keputusan. Penerbit Andi Yogyakarta.,

Aunur R. Mulyanto. (2008). Rekayasa Perangkat Lunak, Penerbit Direktorat Pembinaan Sekolah Menengah Kejuruan, Direktorat Jenderal Manajemen Pendidikan Dasar dan Menengah, Departemen Pendidikan Nasional.,.

Nugroho, Bunafit. (2008). Latihan Membuat Aplikasi Web PHP dan MySQL dengan Dreamweaver. Penerbit Gava Media, Jogjakarta.,

Dramanto, Latifah, \& Susanti. Penerapan Metode AHP (Analytical Hierarchy Process) untuk Menentukan Kualitas Gula Tumbu. SIMETRIS, vol 5 No 1. April 2014. ISSN: 2252-4983.

Hakim, Lukmanul. (2010). Membangun Web Berbasis PHP dengan Framework Codeigniter. Lokomedia, Yogyakarta.,

Kepmen PAN No. 25/M.PAN/2/2004 Tentang Pedoman Umum Penyusunan Indeks Kepuasan Masyarakat Unit Pelayanan Instansi Pemerintah.

Saragih, (2015). Sistem Pendukung Keputusan Penilaian Premises pada BANK CIMB Medan Menggunakan Metode Analytical Hierarchy Process. Pelita Informatika Budi darma, Vol 9 No 2 Maret ISSN: 2301-9425.

Wulandari, (2015). Sistem Pendukung Keputusan Penentu Karyawan Terbaik menggunakan Metode Analytical Hierarchy Process. Pelita Informatika Budi darma, Vol 9 No 3 April. ISSN: 23019425.

Yuliawan, Sunarto \& Soebijono. (2013). Pengembangan Sistem Informasi Pendapatan Jemaat Gereja Masehi Advent Hari Ketujuh Konferens Jiwa Kawasan Timur Berbasis Web. JSIKA Vol 2 No 2 ISSN: 2338-137X. 